DOI: https://doi.org/10.37634/efp.2021.9(1).5

УДК 331.108.26; 331.108 .38

\author{
Oksana KYRYLENKO \\ Doctor of Economics, Professor, Head of department, National Aviation University \\ ORCID: https://orcid.org/0000-0003-2406-7050 \\ e-mail:ons@ua.fm
}

\title{
Vitalii BOROVYK
}

student, National Aviation University

ORCID: https://orcid.org/0000-0002-1221-8117

e-mail:4790091@stud.nau.edu.ua

\section{THEORETICAL AND APPLIED PRINCIPLES OF SYSTEM OF PERSONNEL ADAPTATION}

In modern conditions, as development and reform of economic and socio-labor spheres, continuous technical progress and inconstant world environment, staffing requirements are constantly growing.

Today, important issues for the system of employment and adaptation are their improvement with the help of modern personnel technologies, which would take into account external and internal factors, strategic orientation, could adapt to the natural response to excessive market spontaneity. Staff adaptation is the fundamental basis of any organization and further work with the employee.

The adaptation measures in a complex way, are playing the role of basis for adaptation programs. That program, in turn, describes the tasks, main goals, deadlines and identifies the employees responsible for the adaptation; establishes a sequence of actions to achieve the set goals and indicates what knowledge, skills, competencies and skills a new employee should have and what results he or she should show after the end of the adaptation period.

From the organizational point of view, there are several periods of adaptation. First, this is a familiarization period lasting one month. The second period is an evaluation one. In the third period, there is a gradual integration into the organization. In the article there is identifying of most common features of personnel adaptation system regardless the industry and organization in which that system operates. The goals of personnel adaptation in organization are defined.

In today's labor market, the question of not only the formation of the ideal staff in the organization, but also the retention of valuable staff - this is the task can be performed by an effective system of staff adaptation.

Ключові слова: adaptation, personnel, personnel adaptation, system of personnel adaptation, theoretical bases of adaptation system

\section{INTRODUCTION}

The ways of adjustment to the market environment and level of competition has constantly huge impact on the companies, that have a desire to survive in such "Spartan conditions" and being profitable enough. The list of factors influencing the companies is very large and especial for each market segment and core activity related with the specificity of branch of the economic activity, though the company is operating in supply of goods or services.

In the non-constant world, the huge challenge for any company or enterprise nowadays is to stable in its operational activity with the usage of all possible ways to improve it and achieve better results in the work efficiency. And simultaneously the good co-operated and combined team like a unique single system takes big part of the percentage of success arising.

The term - personnel adaptation become more critical from year to year, especially after the usage of that process has shown positive results on the operational activity and increase in efficiency of activity despite it was processed in company or enterprise.

The management sector defined the need to adapt new employee to the new workplace with the aim to increase the speed of adjustment of that person and becoming the effective part of the staff. The process of adaptation shows the necessity to support newcomers in their adapting procedure, which lead to decrease in needed expenditures and time frames for getting efficient and "profitable" worker.

There huge necessity in that process arose the necessity to overview all circumstances and look at such problem in more complex way. Thus the problem of adaptation of employees to work conditions and other features as a whole was started to be solved by creation of systems of personnel adaptation.

The problem of staff adaptation in the enterprise and its impact on the effectiveness of staff work in various aspects was considered in the scientific publications of many scientists, in particular: D. Ashirov, L. Balabanova, A. Bykova, D. Bogyni, D. Vasilicheva, V. Vasilchenko, O. Vikhansky, A. Volgina, O. Hetman, V. Hrynyova, O. Grishnova, V. Gerasymchuk, A. Hrynenko, M. Doronina, N. Kasyanov, E. Kachan, L. Kerb, A. Kibanova, E. Kobtseva, A. Kolot, V. Kornyushina, O. Krushelnytska, G. Nazarova, V. Ponomarenko, I. Trotskaya, L. Shcherbak, O. Yastremska, et.al.

The PURPOSE of the paper is to describe the theoretical aspects of the personnel adaptation and peculiarities from the side of management over that process.

\section{MATERIALS AND METHODS}

For conducting the research over adaptation processes and measures, such the methodological instruments as analysis, classification and generalization are the most suitable.

Nevertheless, the internal environment of organization should be prepared for critical and extraordinary situations, previously establish the plan of contradicting actions or measures and permanently improve that plans according to the work environment.

It is justified fact, that each new person in organization is not an effective employee until he or she does not finish the process of accommodation to the new workplace, new 
environment, new colleges, etc. That process is much better described as adaptation of personnel, and is presented in any organization or company.

Scientifically substantiated that term "adaptation" arose many centuries ago, however, it was only as a process, which did not have, huge importance.

M.I. Blazhivskyi have considered adaptation as one of the most important scientific problems. He stated that in 1865 the question of adaptation first arose in the scientific world and G. Aubert firstly introduced the term "adaptation", which began to be used in literature. Author says that initially, adaptation was understood as a change in the sensitivity of analyzers under the influence of adaptation of the senses to active aggravators [1].

Most adaptation researchers agree that adaptation is a rather complex phenomenon. Thus, adaptation in a broad sense is interpreted as:

- as a process of adaptation of individual and personal qualities to human life and activity in changing conditions;

- as an active interaction of personality and environment depending on degree of its activity;

- as the transformation of the environment in accordance with the needs and values and the ideals of the individual, or as the benefits of the individual's dependence on the environment;

- as accompanying changes at the level of mental regulation, formation (and restoration), preservation of dynamic balance in the system "subject of labor - professional environment" [1].

In turn, the term adaptation nowadays is present in such activities as technical and social sciences, art and biology, and, of course in HR sector and personnel management as well.

Term "adaptation" as a personnel management aspect is considered as - the process of adjustment of employees to the conditions of the external and internal environment.

The next definition of the term "adaptation" can be the following statement is a process of accommodation of the employee to new for him socio-professional and organizational-economic conditions, inclusion in the system of connections and relations existing in the organization and in structural division [2].

Adaptation is the attachment of an employee to working conditions in a state body, which is based on the gradual development of new professional, social and organizational working conditions [3].

It is scientifically proved, that the interpretation of adaptation as a process of appliance of the employee to the conditions of the enterprise indicates its versatility. It covers the organizational and production environment in which the professional traits of the employee should be optimal in order to achieve the goals of the enterprise.

It means that the process of adaptation and its effecttiveness should be based on mutual coordination of the interests of the employee and the company. Only in this way, the effectiveness of the process of adaptation of the employee and the goals set before the department can be achieved.

Thus, it must be highlighted that most scientists interpret the process of adaptation as a mutual adaptation of the employee to the conditions of the enterprise or organization.

Authors of researches and publications tend to define adaptation as the process of acquainting a novice with the organization and adapting it to the organizational culture, team, and job responsibilities in order to adjust their own behavior in accordance with the formal and informal rules of the organization.

The term "adaptation" is quite common and is used in various fields of science as technical and social sciences, art and biology, in HR sector and personnel management, as well. In sociology and psychology, it is distinguishing between social and industrial adaptation. To some extent, these two types of adaptation intersect with each other, but each of them has its own sphere: social activity is not limited to production, and production includes technical, biological and social aspects.

From the point of view of personnel management, production adaptation plays an important role, because it is the basis for solving such problems as the formation of the required level of productivity and quality of work in a short period.

It is already defined, that adaptation is differentiated in two directions:

Primary, i.e. adaptation of young employees who have no professional experience (graduates of secondary and higher education);

Secondary - means the adaptation of workers in the transition to new ones jobs, positions, facilities.

As a rule, secondary type is faster and easier, though not always. If a person radically changes the profession, then its secondary adaptation may be delayed. The goals of employees 'adaptation are also defined as the division of adaptation of personnel mentioned above and best defined in B.S. Onopriychuk and A.V. Acidic works. That generalized division is presented in Table 1.

The success of adaptation process depends on the nature of production, its environment and the employee. The more complex this environment is, the more different it is from the previous one at the previous place of work, and the more difficult the adaptation process is. Adaptation as a process is characterized by a certain duration and has a start and finish time.

Summarizing the processed sources, from the organizational point of view, there are several periods of adaptation.

First of all, this is a familiarization period lasting one month. During this time, the employee can demonstrate their capabilities, desires, endurance. The second period is an evaluation period, lasting up to one year, when compatibility with the team is achieved.

In the third period there is a gradual integration into the organization. An important role in the effective adaptation of new employees is played by the manager, who conducts a preliminary conversation with employees so that they meet the new employee well, appoints a guardian, studies the state of material working conditions. During the first week, it is desirable that the manager meets with a new employee every day, interested in his success, difficulties. This will allow the manager within a month to learn about the strengths and weaknesses of the new employee, the relationship in the team, his appearance.

As a manager, there is necessity to know why the adaptation period is so important. Here are the reasons why manager should focus attention on it. 
Table 1 - Goals of personnel adaptation in organization [by the authors]

\begin{tabular}{|c|c|}
\hline Primary & Secondary \\
\hline Infusion of young people into organization & Improvement of manufacturing climate \\
\hline Initial division of labor forces & Redistribution of personnel \\
\hline Socialization and professionalization & Preparation of workplace for new employee \\
\hline$\checkmark \quad$ Professional orientation & Increasing of stability level of collective \\
\hline
\end{tabular}

- $\quad$ Reducing the time spent on achieving optimal labor productivity. Any delay in providing new hires with instructions, equipment, resources and the necessary training can slow them down to their expected performance levels. Every day of delay frustrates the employee and can result in the loss of thousands of dollars in profits if it comes to product development or sales.

- Using a new employee as a source of information for recruiting, searching for potential candidates. By asking the newcomer who else was successful in his previous firm, managers can effortlessly replenish their talent pool. Sometimes you can directly ask newcomers to help recruit their former colleagues.

- Conducting competitive intelligence. By asking a newcomer about the best practices in the previous firm, his new manager can get many new ideas.

- Creation of the company's image ("the best place to work"). In the first week, a newbie can call friends dozens of times. How the new employee is treated during this critical period will influence the narratives of how they work. If the reviews are positive, then his friends may want to get a job at your firm. Negative comments can also affect the overall image of the firm and even future sales.

- Clarifying manager's expectations. On the first day, it is important to make sure that the new employee knows what the manager expects of him, what the tasks of the department are and how he personally can contribute to the development of the company.

- Understanding employee expectations. It is equally important for the manager to find out what the new employee's expectations are regarding the conditions and content of work, training, promotion.

- Employee acceptance of the principle of "division of responsibility". It is important to clarify to the new employee that he shares the responsibility of becoming a productive member of the team.

- $\quad$ Support for making a decision about work. The manager needs to "complete the sale" by admiring the new employee and supporting his decision to join the firm. You should answer all the questions of the newbie, dispel his fears and give him information for discussion with friends.

Solving of the problem related with the adaptation of personnel in more broader way stimulate the management of the companies to pay more attention for that topic and thus, in most organizations the complex of measures and instruments with specially appointed persons from the staff create and support the system of personnel adaptation. That system is clearly defined and constructed by the heads of the organization.

\section{RESULTS}

The complexity and multi-vector adaptation of the employee in the environment of new production conditions requires attention from the administration, constant control, analytical monitoring, creation and development of adaptation programs taking into account both subjecttive and objective factors. Such measures can become a successful and effective mechanism of a modern personnel management system.

The result of adaptation depends on a number of conditions of production, organizational, financial, motivational, innovative nature, which requires the improvement of social and labor relations. How this spectrum of relations will develop depends not only on the potential of each individual employee, but also on the enterprise as a whole.

The personnel adaptation system is not only a package of documents regulating the procedure for adapting a new employee. These are, first of all, the people who carry out these activities: both those who directly help the new employee to enter the course of the case, and those who organize and control this process. And, of course, these are the tools they use in their work.

\section{CONCLUSIONS}

It must be highlighted, that continuous and rapid changes in technology make the need in continuous staff development, as knowledge quickly becomes obsolete. Businesses have higher interest to workers with special qualifications, but these same qualifications make workers more mobile in the labor market. In an ever-changing business environment, businesses do not have the possibility to guarantee long-term employment.

In such conditions, companies must have in their arsenal not only modern methods of personnel selection, but also a set of measures and procedures aimed at the most rapid adaptation of staff. The established system of personnel adaptation can become one of the competitive advantages of the enterprise, which, on the one hand, eliminates the negative of staff turnover, and on the other - provides rapid integration of personnel into business processes and its achievement at the optimal level of productivity in the shortest possible time.

\section{$\underline{\text { References }}$}

1. Blazhivskyi M.I. The concept of adaptation in modern science. Scientific Bulletin of Lviv State University of Internal Affairs. 2014. URL: https://www.lvduvs.edu.ua/documents_pdf/visnyky/nvsp/01_2014/14bmisnl.pdf. (in Ukrainian).

2. Pererva A. Adaptation as an adaptation of the employee to working conditions in the state body. Derzhsluzhbovets. 2018.URL:https://i.factor.ua/ukr/journals/ds/2018/july/issue-7/article-37777.html. (in Ukrainian).

3. Adaptation (disambiguation). URL: https://en.wikipedia.org/wiki/Adaptation_(disambiguation) 
4. Demkovych O.S. The essence and main factors of adaptation of the personnel of the enterprises in market conditions of managing. 2012.URL: http://ena.lp.edu.ua:8080/bitstream/ntb/13853/1/9_46-48_Vis_727_Menegment.pdf. (in Ukrainian). (Last accessed: 15.04.2021).

5. Concepts and types of staff adaptation. URL: https://library.if.ua/book/45/3095.html. (in Ukrainian).

6. Staff Adaptation: A Guide for Managers URL: https://hrliga.com/index.php?module=profession\&op=view\&id=97 (in Russian).

7. Krushelnytska O.V., Melnyk D.P. Human Resource. Kyiv: Kondor, 2009. 308 p. (in Ukrainian).

8. Vesnin V.R. Personnel Management. Theory and practice. Moscow: Prospekt, 2009. 688 p. (in Russian).

9. Kibanov A.Y. Organization of personnel management. Moscow: INFRA-M, 2010. 695 p. (in Russian).

\section{Список використаних джерел}

1. Блажівський М.І. Поняття адаптації у сучасній науковій. Науковий Вісник Львівського Держсавного Університету Внутрішніх Справ. 2014. URL: https://www.lvduvs.edu.ua/documents_pdf/visnyky/nvsp/01_2014/14bmisnl.pdf.

2. Перерва А. Адаптація як пристосування працівника до умов праці в державному органі. Держслужбовещъ. 2018.URL: https://i.factor.ua/ukr/journals/ds/2018/july/issue-7/article-37777.html

3. Адаптація (значення). URL: https://uk.wikipedia.org/wiki/Адаптація_(значення)

4. Демкович О.С. Сутність та основні чинники адаптації персоналу підприємств у ринкових умовах господарювання. URL: http://ena.lp.edu.ua:8080/bitstream/ntb/13853/1/9_46-48_Vis_727_Menegment.pdf.

5. Поняття і види адаптації персоналу. URL: https://ibrary.if.ua/book/45/3095.html.

6. Адаптация сотрудников: дуководство для

https:/hrliga.com/index.php?module=profession\&op=view\&id=97.

7. Крушельницька О.В., Мельник Д.П. Управління персоналом. К. : Кондор, 2009. 308 с.

8. Веснин В.Р. Управление персоналом. Теория и практика. М.: Проспект, 2009. 688 с.

9. Кибанов А.Я. Управление персоналом организации. М.: ИНФРА-М, 2010. 695 с.

\section{Оксана Миколаївна КИРИЛЕНКО}

д.е.н., професор, зав. кафедри, Наџіональний Авіаџійний Університет

ORCID: https://orcid.org/0000-0003-2406-7050

e-mail: ons@ua.fm

\section{Віталій Дмитрович БОРОВИК}

студент, Національний Авіаційний Університет

ORCID: https://orcid.org/0000-0002-1221-8117

e-mail: 4790091@stud.nau.edu.ua

\section{ТЕОРЕТИЧНІ ТА ПРИКЛАДНІ ПРИНЦИПИ СИСТЕМИ АДАПТАЦІї ПЕРСОНАЛУ}

У сучасних умовах, у міру розвитку та реформування економічної та соціально-трудової сфер, постійного технічного прогресу та непостійного світового середовища, вимоги до персоналу постійно зростають $і$ змінюються.

Сьогодні важливими питаннями системи зайнятості та адаптації є їх вдосконалення за допомогою сучасних кадрових технологій, які б враховували зовнішні та внутрішні фактори, стратегічну спрямованість, могли б адаптуватися до природного реагування на надмірну стихійність ринку. Адаптація персоналу є фундаментальною основою будь-якої організації та подальшої роботи з прачівником.

Заходи адаптації в комплексі відіграють роль основи програм адаптації. Ця програма, в свою чергу, описує завдання, основні иілі, терміни та визначає прачівників, відповідальних за адаптацію; встановлює послідовність дій для досягнення поставлених цілей та вказує, якими знаннями, вміннями, компетенціями та навичками має володіти новий працівник $і$ які результати він мусить показати після закінчення адаптаційного періоду.

3 організаційної точки зору існує кілька періодів адаптаиії. По-перие, це ознайомчий період, який триває один місяць. Другий період - очіночний, тривалістю до одного року, коли досягається сумісність з командою. Під час третього періоду відбувається поступова інтеграчія в організацію. У статті визначено найбільш загальні особливості системи адаптації персоналу незалежно від галузі та організації, в якій функиіонує ия система. Визначено иџілі адаптації персоналу в організаиії.

На сучасному ринку прачі постає питання не лише про формування ідеального персоналу в організаиії, а й про утримання иінних кадрів, які є набутими організацією - ие є завданням, котре може виконувати ефективна система адаптації персоналу.

Keywords: адаптація, персонал, адаптація персоналу, система адаптаџії персоналу, теоретичні основи системи aдаnтаuฺiï 